\title{
AMELIORATIVE EFFECT OF CIMETIDINE AND SILYMARIN ON ACUTE ACETAMINOPHEN-INDUCED HEPATOTOXICITY IN ADULT ALBINO RATS: AN EXPERIMENTAL COMPARATIVE STUDY
}

\author{
Asmaa A.I. Soliman", Atef Fouda*, Eslam S. Metwally", Abdelmonem G. Madboly ${ }^{*}$ and \\ Rabab F. Hindawy \\ *Forensic Medicine \& Clinical Toxicology Department, Faculty of Medicine, Benha University, \\ Egypt \\ Corresponding Author: Asmaa A.I. Soliman \\ E-mail: Asmaa.ibrahim@ fmed.bu.edu.eg
}

\begin{abstract}
Acetaminophen is an analgesic and antipyretic drug, its overdose cause hepatotoxicity. The current antidote for acetaminophen hepatotoxicity is $\mathrm{N}$-acetyl cysteine (NAC); however, NAC has been resulted in severe side effects as seizures, intracranial hypertension and cerebral edema. This study aimed to assess and compare the ameliorative effects of cimetidine and silymarin against acute acetaminophen-induced hepatotoxicity. Fifty four adult albino rats were divided into nine groups: negative control; solvent control; silymarin control; cimetidine control; cimetidine and silymarin control; acetaminophen group; acetaminophen and silymarin group; acetaminophen and cimetidine group; acetaminophen, cimetidine and silymarin group. A single dose of: acetaminophen $(800 \mathrm{mg} / \mathrm{kg}$, orally); silymarin $(150 \mathrm{mg} / \mathrm{kg}$, orally) and cimetidine $(150 \mathrm{mg} / \mathrm{kg}$, intraperitoneally) were given according to study regimen. Liver histopathology, biochemical analysis of liver aminotransferases (AST \& ALT) and hepatic tissue levels of oxidative stress index (MDA) and antioxidant (GSH) were assessed. Treatment with cimetidine alone gave better biochemical results as compared to treatment with silymarin alone. However combined treatment with cimetidine and silymarin showed better ameliorative effects than either of them given alone, evidenced by better improvement in histopathological examination and biochemical results as compared to other tested groups, and these results were non-significant as compared to controls. In conclusion treatment with silymarin and cimetidine in-combination for acute acetaminophen-induced hepatotoxicity showed better improvement probably due to synergistic hepatoprotective effects.
\end{abstract}

Key words: Acetaminophen, cimetidine, silymarin, hepatotoxicity.

INTRODUCTION

Acetaminophen

[N-acetyl-p-

aminophenol (APAP)] is an over the counter drug, known for its ability to treat fever and pain via direct inhibition of cyclooxygenase (COX)-2 (Salhanik, 2010).

The toxic dose of acetaminophen is highly variable. In adults, single doses above 10 grams or $200 \mathrm{mg} / \mathrm{kg}$ of 
bodyweight have a reasonable likelihood of causing toxicity. Toxicity can also occur when multiple smaller doses within 24 hours exceeds these levels (Daly et al., 2008).

Certain factors can place patients at higher risk of acetaminophen toxicity, such as alcoholism, malnutrition, hepatitis and cancer. This could result in a decreased ability to detoxify NAPQI (Caparrotta et al., 2017).

The hepatotoxic effects of acetaminophen are due to the formation of N-acetyl-p-benzoquinone imine (NAPQI) -a highly toxic byproduct of acetaminophen metabolism- that results in cell injury through oxidative stress (Shan and deval, 2011).

The current antidote for APAPinduced hepatotoxicity is oral or intravenous N-acetyl cysteine (NAC) (Saito et al., 2010).

Nevertheless, $\mathrm{N}$-acetyl cysteine may result in many undesirable side effects; for example: anaphylactoid reactions, seizures, nausea, vomiting, gastroesophageal reflux and cerebral edema (Heard \& schaeffer, 2011).

Cimetidine - a histamine $\mathrm{H}_{2}$ receptor antagonist- can decrease acetaminophen toxic metabolites production by inhibition of cytochrome P450. Its side effects are well known and take place only at very high doses and its use in combination with NAC can be effective in acute acetaminophen poisoning (Ebrahimi et al., 2015).

Silymarin is a flavonoid extracted from the seed of milk thistle plant. It is an herbal medication used as a liver protective therapy due to its antioxidant activity, with very mild side effects
(Anthony \& Saleh, 2013; Hellerbrand et al., 2016).

Several studies were conducted to evaluate the role of cimetidine and silymarin as adjuvant therapies in acetaminophen-induced hepatotoxicity, but the comparison between them as a main line of treatment as well as their use in-combination as heatoprotective agents in acetaminophen-induced hepatotoxicity are not well assessed.

\section{AIM OF THE WORK}

The present work was conducted to assess and compare the ameliorative effects of cimetidine and silymarin (either given alone or in-combination) against acute acetaminophen-induced hepatotoxicity in adult albino rats.

\section{MATERIALS AND METHODS \\ Animals:}

The present work was carried out on fifty four Wistar male albino rats of 200 $( \pm 10)$ g. All rats were allowed for one week of adaptation (taking food \& water without any medications) in their new environment at Anatomy Department, Faculty of Medicine, Benha University.

This research was accepted by the local Ethical Committee, Banha Faculty of Medicine.

\section{Chemicals:}

Silymarin powder of purity $\pm 99 \%$ was purchased from SEDICO, "6 October" City - Egypt. Acetaminophen powder of purity $\pm 99 \%$ and cimetidine powder of purity $\pm 99 \%$ were obtained from Sigma Chemical Co., United States. Other chemicals and reagents were of extreme analytical grade. 


\section{Animal groups:}

At the beginning of the study, animals were randomly classified into nine groups (six/group):

- Group I (negative control): left without intervention to measure the basic parameters, free access to food and distilled water was allowed through entire period of study.

- Group II (solvent control): rats of this group received distilled water; either $0.5 \mathrm{ml}$ intraperitoneally (three rats) or $1 \mathrm{ml}$ orally (three rats).

- Group III (silymarin control): rats of this group received a single dose of silymarin $150 \quad \mathrm{mg} / \mathrm{kg}$ orally (Kazemifar et al., 2012)

- Group IV (cimetidine control): rats of this group received a single dose of cimetidine $150 \mathrm{mg} / \mathrm{kg}$ intraperitoneally (IP) (Al-Mustafa et al., 1997).

- Group V (cimetidine + silymarin control): rats of this group received a single dose of cimetidine 150 $\mathrm{mg} / \mathrm{kg}$ IP (Al-Mustafa et al., 1997) and a single dose of silymarin $150 \mathrm{mg} / \mathrm{kg}$ orally (Kazemifar et al., 2012).

- Group VI (acetaminophen): rats of this group received a single toxic dose of acetaminophen $800 \mathrm{mg} / \mathrm{kg}$ orally (Kazemifar et al., 2012).

- Group VII (acetaminophen + silymarin): rats of this group received a single dose of acetaminophen $800 \mathrm{mg} / \mathrm{kg}$ orally followed by a single dose of silymarin $150 \mathrm{mg} / \mathrm{kg}$ orally, two hours after acetaminophen dose (Kazemifar et al., 2012).

- Group VIII (acetaminophen + cimetidine): rats of this group received a single dose of acetaminophen $800 \mathrm{mg} / \mathrm{kg}$ orally (Kazemifar et al., 2012) followed by a single dose of cimetidine $150 \mathrm{mg} / \mathrm{kg}$ IP, two hours after acetaminophen dose (Al-Mustafa et al., 1997).
- Group IX (acetaminophen + cimetidine + silymarin): rats of this group received a single dose of acetaminophen $800 \quad \mathrm{mg} / \mathrm{kg}$ orally followed by a single dose of silymarin $150 \mathrm{mg} / \mathrm{kg}$ orally, two hours after acetaminophen dose (Kazemifar et al., 2012), and a single dose of cimetidine $150 \mathrm{mg} / \mathrm{kg}$ IP, two hours after acetaminophen dose (Al-Mustafa et al., 1997).

After 72 hours [the end of the experiment], rats were anaesthetized with ether inhalation, the abdominal cavity was opened, blood samples were collected from heart and processed for biochemical measurements. The liver was removed, cleaned and divided into 2 parts. One part was placed in 10\% formalin for histopathological study. The second part was kept at $-80^{\circ} \mathrm{C}$ and used for biochemical measurement of malondialdehyde (MAD) and reduced glutathione (GSH), after it was homogenized in $10 \mathrm{ml}$ of ice cold phosphate buffer. The homogenate was centrifuged and the clear supernatants were separated for biochemical analysis.

\section{Studied parameters:}

A) Biochemical study:

1- Liver enzymes:

- Alanine aminotransferase (ALT) level was calculated spectrophotometrically using the commercial test of SGPT (ALT) with spinlab (Spinreact company), Spain.

- Aspartate aminotransferase (AST) level was calculated spectrophotometrically using the commercial test of SGOT (AST) with spinlab (Spinreact company), Spain.

2- Oxidative stress indices: 
- The malondialdehyde (MDA) concentration in hepatic tissue samples was determined using the method described by Chattopadhyay et al. (2003).

3- Antioxidants:

- Reduced glutathione (GSH) was measured using the method of Beulter et al. (1963).

\section{B) Histopathological study:}

- Sections of hepatic tissue were examined by light microscope, after they were stained with Haematoxylin and Eosin (H\&E) according to (Lamberg and Rothstein, 1978).

\section{Statistical analysis:}

The SPSS version 21 software (Spss Inc, Chicago, ILL Company) was used to analyze the collected data. The Kruskal Wallis test was used to detect difference among the studied groups. The accepted level of significance was stated at $0.05(\mathrm{P}$ $<0.05$ was considered significant) (Khothari, 2004).

\section{RESULTS}

A) Biochemical study:

In the present work negative control, solvent control, silymarin control, cimetidine control and "silymarin + cimetidine control" groups, showed a non-significant difference $(\mathrm{p}>0.05)$ as regard biochemical parameters (ALT, AST, MDA and GSH), as showed in table 1 . So, the mean of all control groups was chosen as a representative group for the five control groups to be compared with the results of the tested groups.

A highly significant difference $(\mathrm{p}<0.001)$ between studied groups as regard the levels of serum ALT and ALT as well as liver tissue levels of MDA and GSH was observed, as illustrated in tables 2-5.
The present work detected a highly significant $(\mathrm{p}<0.001)$ reduction in ALT and AST serum levels, and MDA liver tissue levels and a highly significant $(\mathrm{p}<0.001)$ increase in GSH levels in liver tissue in group VIII (acetaminophen + cimetidine) as compared to group VII (acetaminophen + silymarin), but these levels were still higher than that of the control group (showed significant difference with controls), as showed in tables 2-5.

The present work showed a highly significant $(p<0.001)$ decrease in levels of ALT, AST, MDA, and a highly significant $(p<0.001)$ increase in GSH in group IX (acetaminophen + cimetidine + silymarin) as compared to group VI (acetaminophen), group VII (acetaminophen + silymarin) and group VIII (acetaminophen + cimetidine) and these results were non-significant as compared to controls, as showed in table 6 .

\section{B) Histopathological study:}

In control groups (negative control, solvent control, silymarin control, cimetidine control and "silymarin + cimetidine"); sections from the liver tissue of rats showed similar structures with no significant histopathological changes. A Figure of the negative control group was used as a representative for other control groups, fig. (1).

Histopathological results supported the evidence of biochemical parameters analyzed in this study, as sections of rat liver treated with acetaminophen showed significant hepatotoxicity, characterized by degeneration of hepatocytes (hydropic degeneration), dilatation of the blood sinusoids and congestion of central vein. The damage extended to most of the hepatic lobule with marked loss of its normal pattern, as showed in fig. (2).

Liver sections in rat groups either treated with acetaminophen and cimetidine or 
acetaminophen and silymarin revealed that there was some improvement of liver regenerative changes as compared to acetaminophen treated group but failed to have the same picture observed in the normal control group, as illustrated in fig. ( $3 \& 4)$.

Liver sections in rats treated with combination of silymarin and cimetidine showed better improvement in the hepatic architecture and better improvement in liver morphology than that produced by either silymarin or cimetidine alone, as showed by apparent normal hepatic architecture in fig. (5).

Table (1): Comparison between control groups regarding alanine aminotransferase (ALT), aspartate aminotransferase (AST), malondialdehyde (MDA) and reduced glutathione (GSH) [No. of each=6]

\begin{tabular}{|c|c|c|c|c|c|c|c|c|c|c|c|c|}
\hline \multirow{2}{*}{ Groups } & \multicolumn{3}{|c|}{$\overline{\text { ALT }}$} & \multicolumn{3}{|c|}{$\overline{\mathrm{AST}}$} & \multicolumn{3}{|c|}{ MDA } & \multicolumn{3}{|c|}{$\overline{\text { GSH }}$} \\
\hline & $\begin{array}{c}\text { Mea } \\
\text { n }\end{array}$ & $\begin{array}{c} \pm \\
\text { SD }\end{array}$ & $\begin{array}{c}\text { Ran } \\
\text { ge }\end{array}$ & $\begin{array}{c}\text { Mea } \\
\mathbf{n}\end{array}$ & $\pm \mathrm{SD}$ & $\begin{array}{c}\text { Rang } \\
\text { e }\end{array}$ & $\begin{array}{c}\text { Mea } \\
\mathbf{n}\end{array}$ & \pm SD & $\begin{array}{c}\text { Rang } \\
\text { e }\end{array}$ & $\begin{array}{c}\text { Mea } \\
\text { n }\end{array}$ & $\begin{array}{c} \pm \\
\text { SD }\end{array}$ & $\begin{array}{c}\text { Rang } \\
\text { e }\end{array}$ \\
\hline $\begin{array}{l}\text { Group I (negative } \\
\text { control) }\end{array}$ & 40.7 & $\begin{array}{l}0.3 \\
3 \\
\end{array}$ & $\begin{array}{l}40.3- \\
41.2\end{array}$ & 45.8 & 0.60 & $\begin{array}{l}45- \\
46.5\end{array}$ & 43.3 & 0.32 & $\begin{array}{l}42.9- \\
43.8\end{array}$ & 10.4 & $\begin{array}{l}0.2 \\
7 \\
\end{array}$ & $\begin{array}{l}10.1- \\
10.9\end{array}$ \\
\hline $\begin{array}{l}\text { Group II (solvent } \\
\text { control) }\end{array}$ & 40.2 & $\begin{array}{l}0.6 \\
3 \\
\end{array}$ & $\begin{array}{l}39.3- \\
41.2\end{array}$ & 44.8 & 0.83 & $\begin{array}{l}43.2- \\
45.5\end{array}$ & 43.7 & 0.82 & $\begin{array}{l}42.8- \\
44.8\end{array}$ & 10.2 & $\begin{array}{l}0.1 \\
7 \\
\end{array}$ & $\begin{array}{l}9.98- \\
10.4\end{array}$ \\
\hline $\begin{array}{l}\text { Group III } \\
\text { (silymarin }\end{array}$ & 40.1 & $\begin{array}{l}0.4 \\
8 \\
\end{array}$ & $\begin{array}{l}39.3- \\
40.5\end{array}$ & 45.7 & 0.38 & $\begin{array}{l}45.2- \\
46.1\end{array}$ & 43.0 & 0.52 & $\begin{array}{l}42.3- \\
43.9\end{array}$ & 10.6 & $\begin{array}{l}0.2 \\
7 \\
\end{array}$ & $\begin{array}{l}10.3- \\
10.99\end{array}$ \\
\hline $\begin{array}{l}\text { Group IV } \\
\text { (cimetidine }\end{array}$ & 40.6 & $\begin{array}{l}0.7 \\
5\end{array}$ & $\begin{array}{l}39.8- \\
41.6\end{array}$ & 45.7 & 0.63 & $\begin{array}{l}45- \\
46.6\end{array}$ & 42.8 & 0.46 & $\begin{array}{l}42- \\
43.3\end{array}$ & 10.5 & $\begin{array}{l}0.3 \\
3\end{array}$ & $\begin{array}{l}10.1- \\
10.9\end{array}$ \\
\hline $\begin{array}{l}\text { Group V } \\
\text { (silymarin }\end{array}$ & 41.4 & $\begin{array}{l}0.8 \\
9\end{array}$ & $\begin{array}{l}40- \\
42.4\end{array}$ & 45.5 & 0.73 & $\begin{array}{l}45- \\
46.9\end{array}$ & 43.1 & 0.24 & $\begin{array}{l}42.8- \\
43.5\end{array}$ & 10.6 & $\begin{array}{l}0.3 \\
3\end{array}$ & $\begin{array}{l}10.1- \\
10.99\end{array}$ \\
\hline KW test & \multicolumn{3}{|c|}{9.26} & \multicolumn{3}{|c|}{5.87} & \multicolumn{3}{|c|}{7.6} & \multicolumn{3}{|c|}{7.21} \\
\hline $\mathbf{P}$ & \multicolumn{3}{|c|}{$0.055(\mathrm{NS})$} & \multicolumn{3}{|c|}{0.209 (NS) } & \multicolumn{3}{|c|}{0.107 (NS) } & \multicolumn{3}{|c|}{$0.125(\mathrm{NS})$} \\
\hline
\end{tabular}

KW test $\rightarrow$ Kruskal Wallis test, NS: non-significant 
Table (2): Comparison between studied groups regarding alanine aminotransferase (ALT) serum level

\begin{tabular}{|l|c|c|c|c|c||}
\hline \multirow{2}{*}{\multicolumn{1}{|c|}{ Groups }} & \multicolumn{3}{c|}{ ALT } & \multirow{2}{*}{$\begin{array}{c}\text { KW } \\
\text { test }\end{array}$} & P \\
\cline { 2 - 5 } & Mean & \pm SD & Range & \\
\cline { 1 - 5 } Control & 40.6 & 0.76 & $39.3-42.4$ & \multirow{3}{*}{39.9} & $<0.001$ \\
Group VI (acetaminophen) & 164.3 & 2.58 & $160-168$ & & (HS) \\
\hline Group VII (acetaminophen +silymarin) & 76.8 & 0.61 & $76-77.6$ & & \\
\hline Group VIII (acetaminophen + cimetidine) & 67.4 & 1.13 & $66-69$ & & \\
\hline Group IX (acetaminophen +silymarin & 41.4 & 0.28 & $41.1-41.9$ & & \\
\hline
\end{tabular}

$K W$ test $\rightarrow$ Kruskal Wallis test, HS: high significant

Table (3): Comparison between studied groups regarding aspartate aminotransferase (AST) serum level

\begin{tabular}{||l|c|c|c|c|c|}
\hline \multirow{2}{*}{\multicolumn{1}{|c|}{ Groups }} & \multicolumn{3}{c|}{ AST } & \multirow{2}{*}{$\begin{array}{c}\text { KW } \\
\text { test }\end{array}$} & \multirow{2}{*}{ P } \\
\cline { 2 - 5 } & Mean & \pm SD & Range & \\
\hline Control & 45.5 & 0.71 & $43.2-46.9$ & & \\
\cline { 1 - 4 } Group VI (acetaminophen) & 173.8 & 3.06 & $170-177$ & \multirow{3}{*}{38.3} & $<0.001$ \\
\cline { 1 - 4 } Group VII (acetaminophen +silymarin) & 97.6 & 0.58 & $97-98.4$ & & \\
\cline { 1 - 4 } Group VIII acetaminophen + cimetidine) & 79.6 & 0.76 & $78.5-80.5$ & & \\
\hline Group IX (acetaminophen +silymarin & 44.4 & 1.50 & $42.3-45.8$ & & \\
\hline
\end{tabular}

KW test $\rightarrow$ Kruskal Wallis test, HS: high significant

Table (4): Comparison between studied groups regarding malondialdehyde (MDA) hepatic tissue level

\begin{tabular}{|c|c|c|c|c|c|}
\hline \multirow{2}{*}{ Groups } & \multicolumn{3}{|c|}{$\overline{\text { MDA }}$} & \multirow{2}{*}{$\begin{array}{l}K W \\
\text { test }\end{array}$} & \multirow{2}{*}{$\mathbf{P}$} \\
\hline & Mean & \pm SD & Range & & \\
\hline Control & 43.2 & 0.58 & $42.0-44.8$ & \multirow{5}{*}{40.6} & \multirow{5}{*}{$\begin{array}{c}<0.001 \\
(\mathrm{HS})\end{array}$} \\
\hline Group VI (acetaminophen) & 181.9 & 1.42 & $180-183.3$ & & \\
\hline Group VII (acetaminophen +silymarin) & 80.6 & 0.52 & $80-81.4$ & & \\
\hline Group VIII (acetaminophen +cimetidine) & 74.3 & 1.01 & 73-75.4 & & \\
\hline $\begin{array}{l}\text { Group IX (acetaminophen +silymarin } \\
\text { +cimetidine) }\end{array}$ & 44.0 & 0.66 & $43.2-45$ & & \\
\hline
\end{tabular}

$K W$ test $\rightarrow$ Kruskal Wallis test, HS: high significant 
Table (5): Comparison between studied groups regarding reduced glutathione (GSH) hepatic tissue level

\begin{tabular}{|l|c|c|c|c|c||}
\hline \multirow{2}{*}{ Groups } & \multicolumn{3}{c|}{ GSH } & \multirow{2}{*}{ KW } & \multirow{2}{*}{ P } \\
test & & \\
\cline { 2 - 5 } Control & Mean & \pm SD & Range & & \\
\cline { 1 - 4 } Group VI (acetaminophen) & 10.4 & 0.30 & $9.98-10.99$ & & \\
\cline { 1 - 4 } Group VII (acetaminophen +silymarin) & 5.4 & 0.27 & $5.1-5.92$ & 1.0 & $<0.001$ \\
\cline { 1 - 4 } Group VIII (acetaminophen +cimetidine) & 6.2 & 0.14 & $6.1-6.5$ & & \\
\cline { 1 - 4 } $\begin{array}{l}\text { Group IX (acetaminophen +silymarin } \\
\text { +cimetidine) }\end{array}$ & 10.0 & 0.27 & $9.5-10.3$ & & \\
\hline
\end{tabular}

KW test $\rightarrow$ Kruskal Wallis test, HS: high significant

Table (6): Comparison between group IX (acetaminophen + silymarin +cimetidine) and other studied groups by Bonferroni test for detection of significant pairs regarding the studied parameters

\begin{tabular}{||l|c|c|c|c||}
\hline $\begin{array}{c}\text { Group IX } \\
\text { (acetaminophen }+ \\
\text { silymarin } \\
\text { +cimetidine) }\end{array}$ & Controls & $\begin{array}{c}\text { Group VI } \\
\text { (acetaminophen) }\end{array}$ & $\begin{array}{c}\text { Group VII } \\
\text { (acetaminophen } \\
\text { +silymarin) }\end{array}$ & $\begin{array}{c}\text { Group VIII } \\
\text { (acetaminophen + } \\
\text { cimetidine) }\end{array}$ \\
\cline { 2 - 5 } & $\mathrm{P}$ & $\mathrm{P}$ & $\mathrm{P}$ & $\mathrm{P}$ \\
\hline ALT & $1.0(\mathrm{NS})$ & $<0.001(\mathrm{HS})$ & $<0.001(\mathrm{HS})$ & $<0.001(\mathrm{HS})$ \\
\hline AST & $0.58(\mathrm{NS})$ & $<0.001(\mathrm{HS})$ & $<0.001(\mathrm{HS})$ & $<0.001(\mathrm{HS})$ \\
\hline MDA & $0.22(\mathrm{NS})$ & $<0.001(\mathrm{HS})$ & $<0.001(\mathrm{HS})$ & $<0.001(\mathrm{HS})$ \\
\hline GSH & $0.061(\mathrm{NS})$ & $<0.001(\mathrm{HS})$ & $<0.001(\mathrm{HS})$ & $<0.001(\mathrm{HS})$ \\
\hline
\end{tabular}




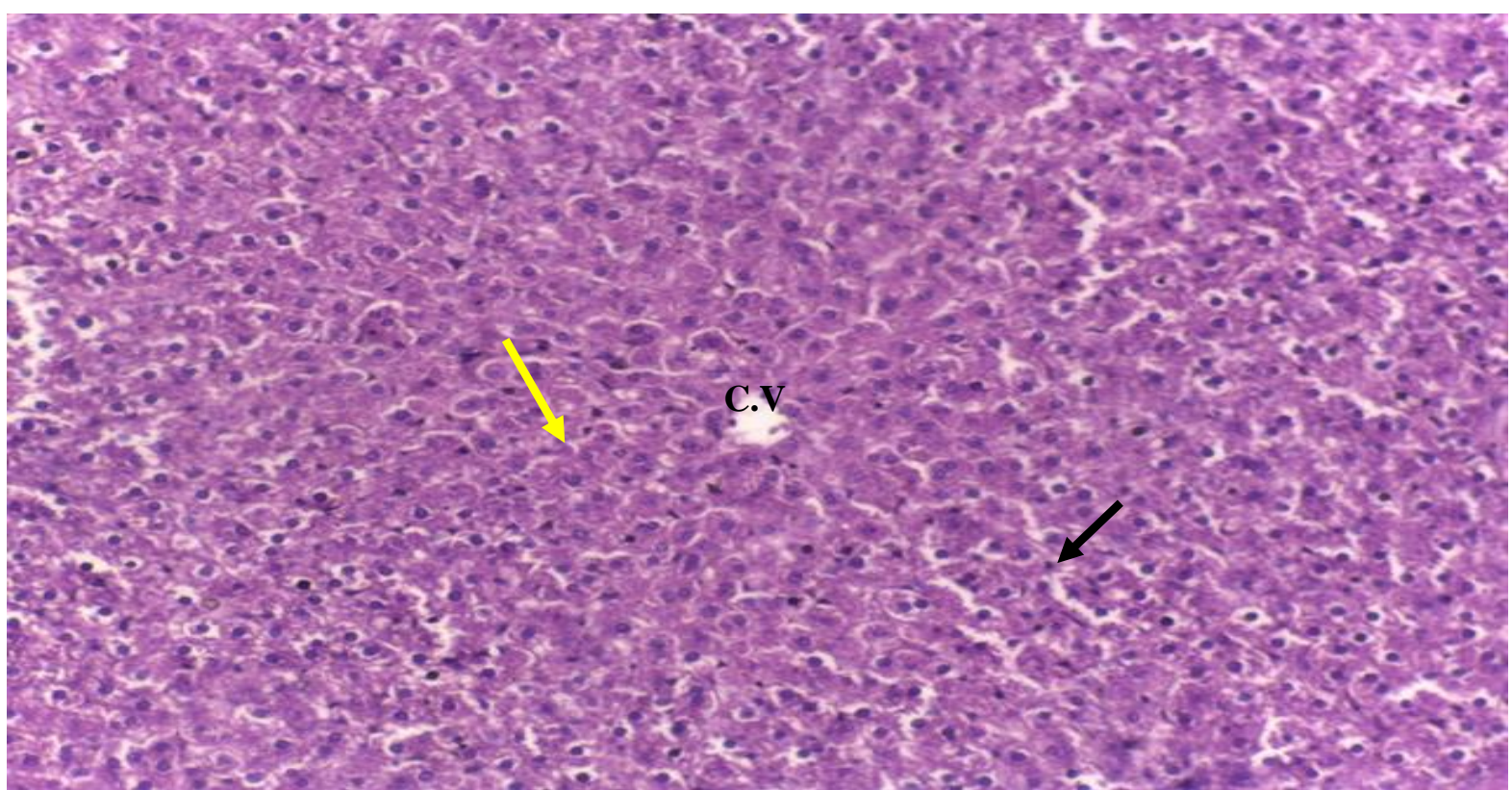

Fig. (1): A photomicrograph of a section from a rat's liver of negative control group showed normal hepatic plates radiating from a thin walled central vein $(\mathrm{CV})$ separated by normal sized blood sinusoids (black-rrows ), polyhedral hepatocytes contained rounded vesicular nucle: allow arrows $\quad$ ) and eosinophilia cytoplasm $(\mathbf{H \& E}, \mathbf{x 2 0 0})$.

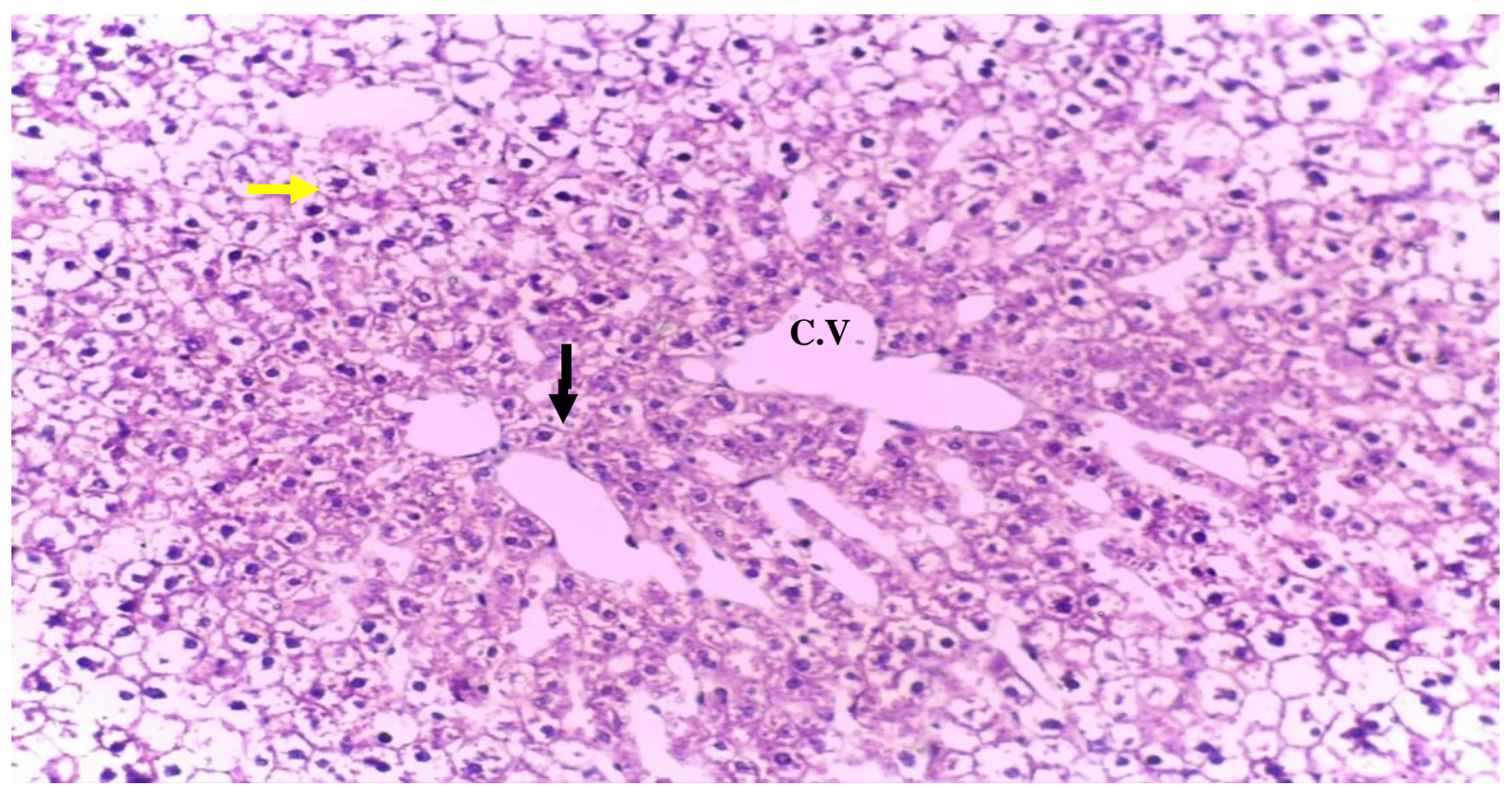

Fig.(2): A photomicrograph of a section from a rat's liver of acetaminophen treated group showed dilated blood sinusoids ( black arrows $\rightarrow$ ), hepatocytes swollen and showed severe hydropic degeneration with foemy granular cytoplasm ( yellow arrows $\rightarrow$ ) and dilated congested central vein $(\mathrm{CV})(\mathbf{H \& E}, \mathbf{x 2 0 0})$. 


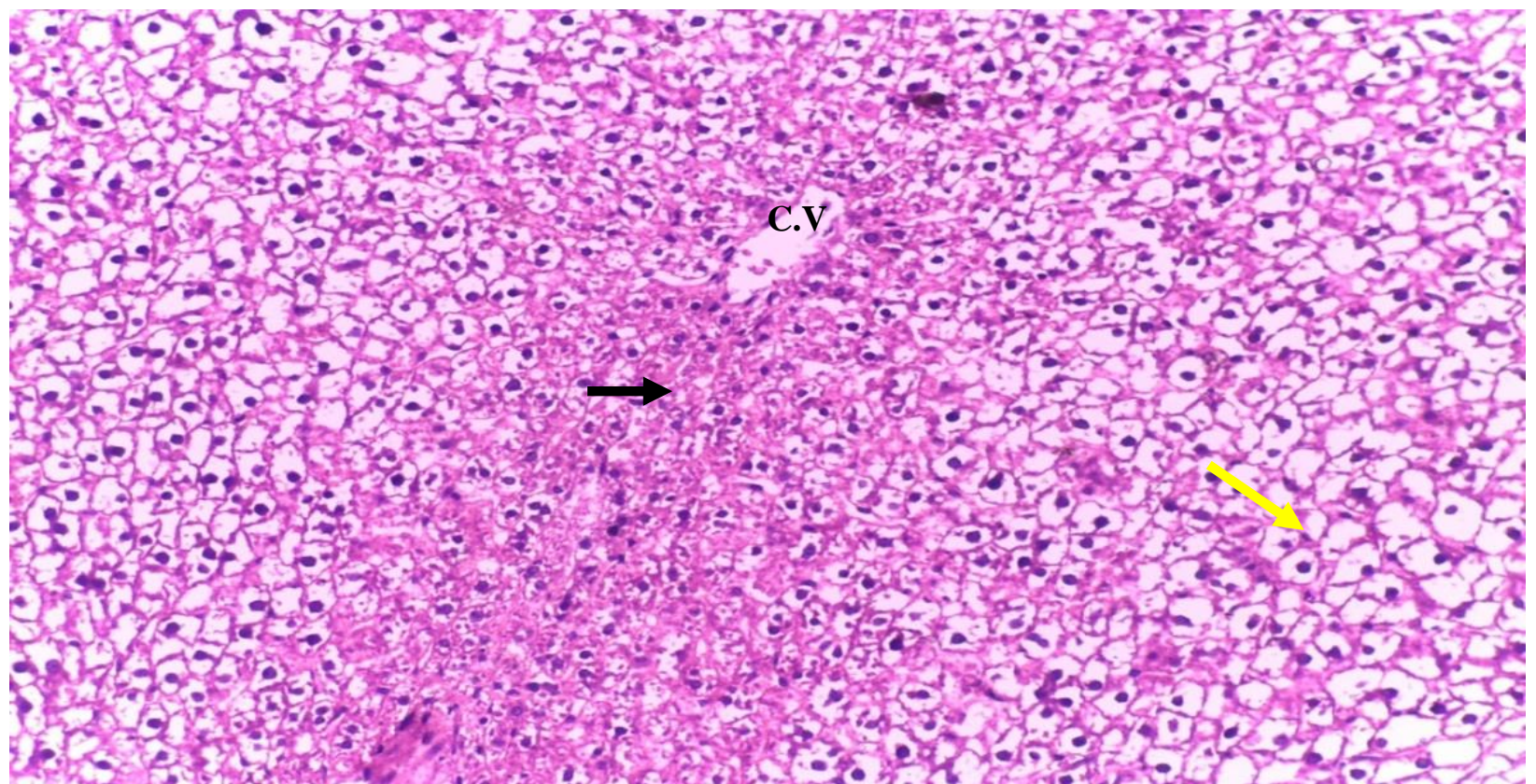

Fig.(3): A photomicrograph of a section from a rat's liver of acetaminophen and cimetidine treated group showed hepatocytes around central vein (CV) which was normal with eosinophilic cytoplasm arrows ) and the hepatocytes away from central vein still showing hydropic degeneration (yellc $\cdots$ arrows ), there was no dilatation and congestion of central vein $(\mathrm{CV})$ or dilatation of blood sinusoids $(\mathbf{H \& E}, \mathbf{x 2 0 0})$.

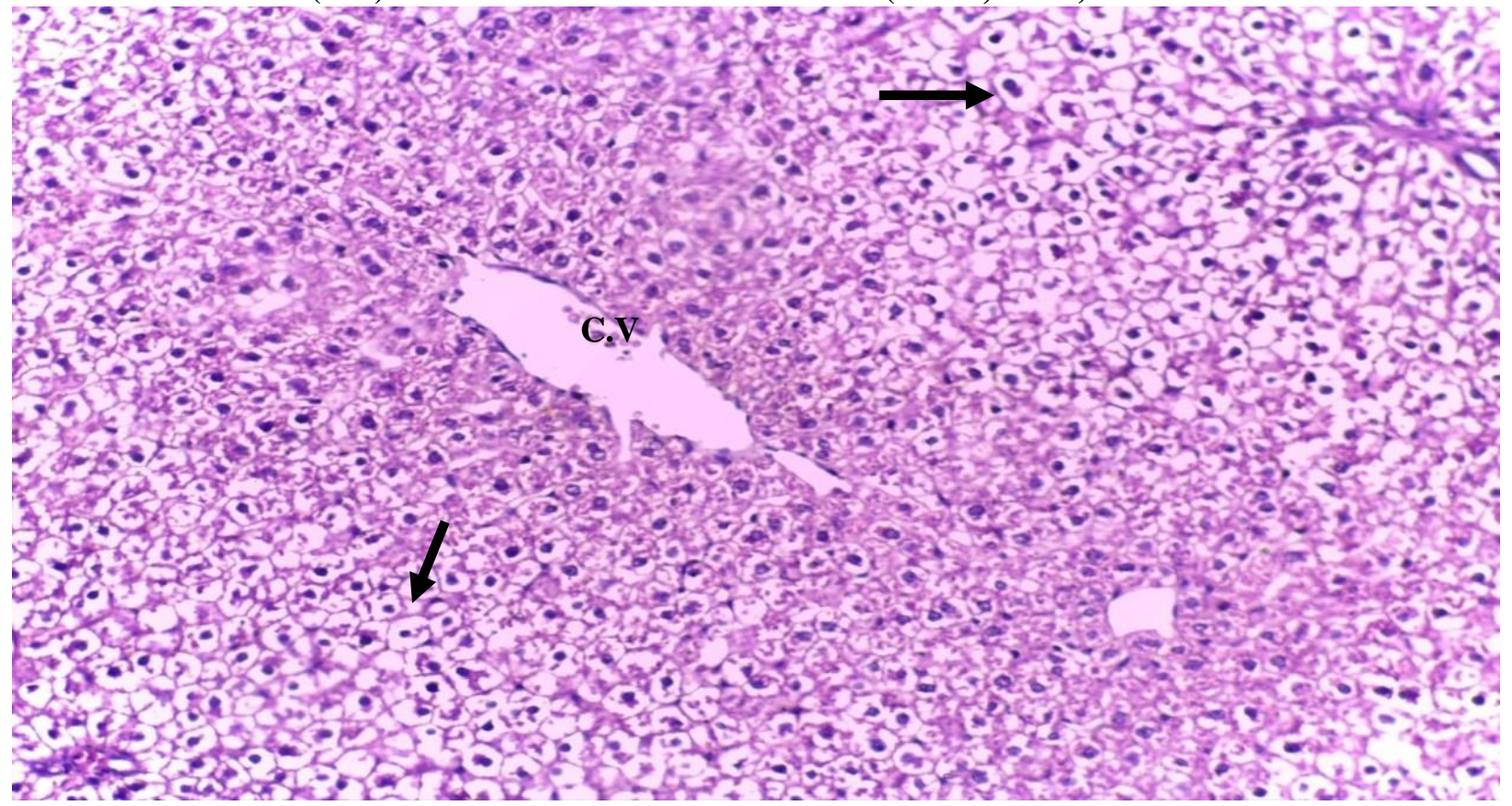

Fig.(4): A photomicrograph of a section from a rat's liver of acetaminophen and silymarin treated group showed hepatocytes with hydropic degeneration with foemy granular cytoplasm (black arrows $\longrightarrow$ ), central vein $(\mathrm{CV})$ was dilated and there was no dilatation of blood sinusoids (H\&E, x200) . 


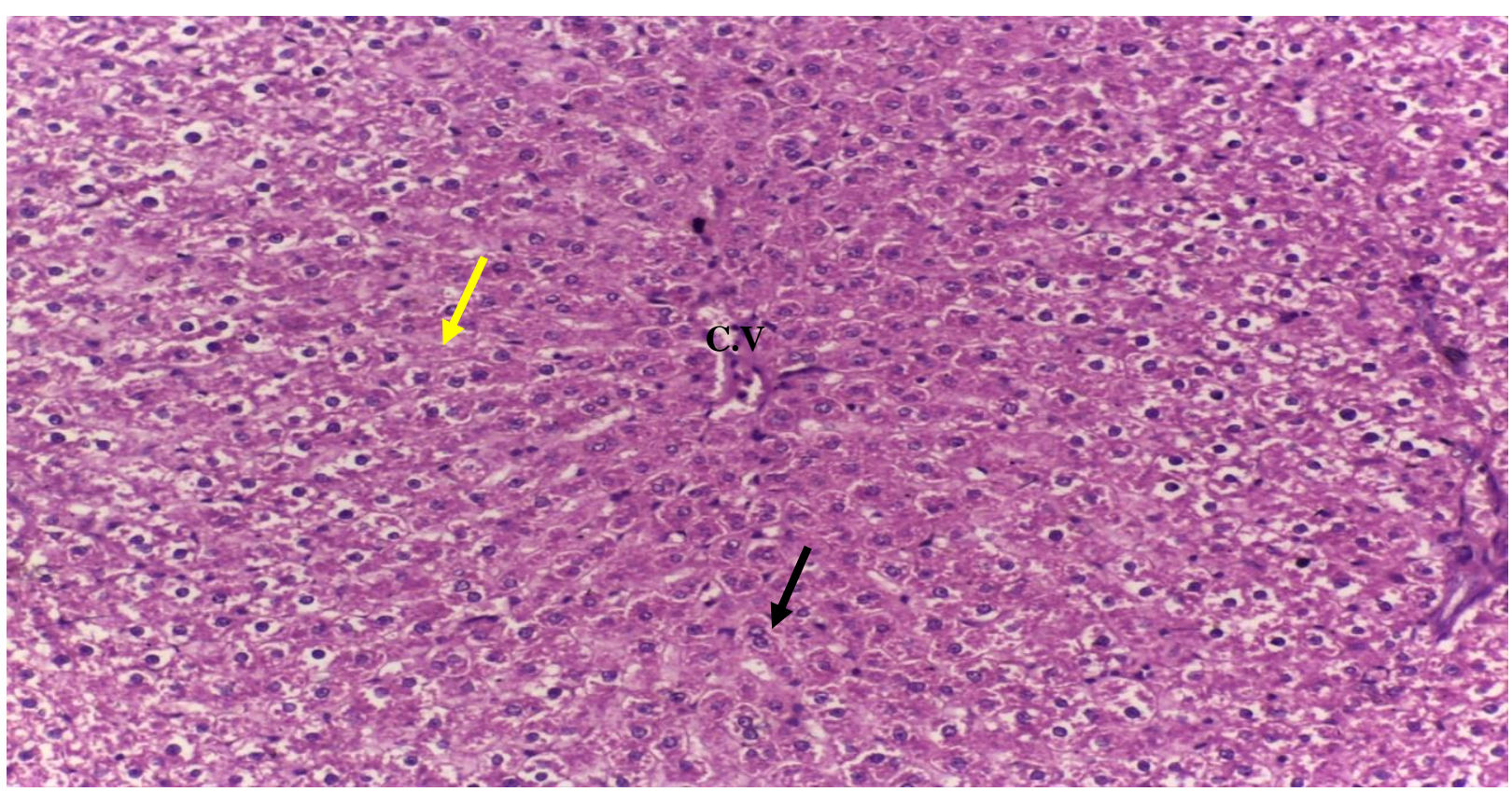

Fig.(5) :A photomicrograph of a section from a rat's liver of acetaminophen, silymarin and cimetidine treated group showed normal sized central vein (CV), normal blood sinusoids (black arrows $\longrightarrow$ ) and normal hepatocytes with eosinophilic cytoplasm and rounded vesicular nuclei (yellow arrows $\Longrightarrow$ ) indicating regenerative changes with significant sustained hepatic architecture almost similar to control group (H\&E, x200). 


\section{DISCUSSION}

Acetaminophen is a common drug used to investigate the hepatoprotective role of different therapies (Suresh et al., 2006; and Abirami et al., 2015).

Silymarin has been reported to exert several mechanisms against different hepatotoxic drugs (Pandey et al., 2011).

Cimetidine is a well-known inhibitor for CYP3A4 and CYTP2D6 isoenzymes of the CYP450 enzyme system, so it is used as adjuvant therapy for acetaminophen hepatotoxicity (Jahangirvand et al., 2016).

The present work showed a highly significant $(\mathrm{p}<0.001)$ increase in both AST, and ALT serum levels in acetaminophen treated group, as compared to control groups.

These findings are in accordance with those achieved by Singh et al. (2012); Adebiyi and Abatan (2013); Arote et al. (2014); Hamza and Al-Harbi (2015) and Sabiu et al. (2015).

It is well recognized that serum transaminases are very sensitive as indicators of hepatocyte damage and their levels remain high as far as liver damage persist (ElAshmawy et al., 2005 and Suleyman et al., 2015).

The marked release of transaminases into the blood stream was due to hepatocytic necrosis with cell membrane degradation (Bairwa et al., 2010).

The present work demonstrated that administration of silymarin with acetaminophen was able to suppress acetaminophen-induced hepatocellular injury as evidenced by significant $(\mathrm{p}<0.001)$ reduction of serum ALT, AST levels compared to acetaminophen treated group.

These findings are in line with those detected by Datta et al. (2013) and Sabina et al. (2013) who found that silymarin diminished hepatotoxicity of acetaminophen in rats, and led to decrease in serum ALT and AST levels.

This protective effect of silymarin is due to maintaining cell membrane integrity meditated by its antioxidants activity and its ability to neutralize free radicals, thus preventing liver call injury and leakage of enzymes to the circulation (Pradeep et al., 2007; Rajasekaran and Periyasamy, 2012).

The present work illustrated that treatment with cimetidine two hours after acetaminophen-induced hepatotoxicity gave better biochemical results as compared to treatment with silymarin, as rat group treated with acetaminophen and cimetidine demonstrated a highly significant $(\mathrm{p}<0.001)$ decrease in serum levels of ALT, AST when compared to those treated with acetaminophen and silymarin, nevertheless, these levels were still higher than that of the control group (showed significant difference with controls).

These results are in agreement with Adikwu and Bokolo (2018) who found that cimetidine ameliorates the increase in serum liver enzymes (ALT, AST) due to cyclophosphamide-induced liver toxicity in albino rats.

Previous study stated that cimetidine at a dose of $400 \mathrm{mg} / \mathrm{kg}$, is highly effective in protecting the liver against acetaminopheninduced hepatotoxicity, thus reaffirming its potential role as an antidote (Juma et al., 2015).

Mc Quaid (2003); Javad et al. (2009) and Gaafa et al., (2011) concluded that cimetidine is more useful in the treatment of acetaminophen overdose because of its hepatic microsomal enzyme system inhibitory effect mainly CYP3A4 and CYP2D6 leading to decrease in NAPQI formation even before hepatotoxicity occurs.

Cimetidine protective role could be also attributed to its antioxidant activity through the scavenging of oxidative radicals 
generated by acetaminophen-induced hepatotoxicity (Adikwu and Bokolo, 2018).

The present work demonstrated that combined treatment with cimetidine and silymarin for hepatotoxicity induced by acetaminophen showed better improvement than either of them given alone, as in group IX (acetaminophen + cimetidine + silymarin) there was a highly significant $(\mathrm{p}<0.001)$ decrease in levels of ALT, AST as compared to group VI (acetaminophen), group VII (acetaminophen + silymarin) and group VIII (acetaminophen + cimetidine) and these results were non-significant as compared to controls.

Zira et al. (2009) found that silymarin and cimetidine co-administration with acetaminophen improved the AST and ALT levels, probably due to additive hepatoprotective effect.

Malondialdehyde (MDA) is the end product of lipid peroxidation and its concentration in liver will increase in oxidative stress and liver injury (Akindele and Adeyemi, 2010; Abdel-Hady and AbdelRahman, 2013).

In the present work, a significant elevation in the levels of MDA in liver of acetaminophen treated group as compared to normal control group was observed.

Other reported studies done by Hamza and Al-Harbi (2015); Sabiu et al. (2015) also, showed increase in the MDA levels indicating an increase in the generation of free radicals in the paracetamol treated rats.

Navdeep et al. (2010) stated that elevation in hepatic tissue MDA levels indicates the increase in lipid peroxidation with cellular injury and failure of antioxidant defense mechanisms.

In the current study, treatment with silymarin significantly decreased liver MDA level as compared to acetaminophen treated group.

Girish et al. (2009); Galal et al. (2012) and El-Sayed et al. (2015) found that silymarin markedly recovered the changes in hepatic MDA, GSH and NO contents in rats subjected to acetaminophen-intoxication as it possibly acts as a free radical scavenger and a plasma membrane stabilizer.

The present work showed that treatment with cimetidine two hours after acetaminophen-induced hepatotoxicity demonstrated a highly significant $(\mathrm{p}<0.001)$ decrease in MDA level when compared to those of acetaminophen treated group or acetaminophen and silymarin treated group, but these levels were still higher than that of the control group (showed significant difference with controls).

Ahmadi et al. (2011) found that cimetidine decreased MDA level and reduce lipid peroxidation in carbon tertrachloride (CCL4) induced liver damage.

The hepatoprotective effects of cimetidine may be related to its antioxidant activity in scavenging free radicals and free oxygen species such as $\mathrm{O}^{2-}$ and $\mathrm{OH}^{-}$(Adikwu and Bokolo, 2018).

Gaafa et al. (2011) stated that cimetidine prevents diethyldithiocarbamate (DDC) induced MDA formation due to its suppressive effect on the release of nonprotein-bound iron chelates from cytochrome P450.

The present work showed that combined treatment with cimetidine and silymarin for hepatotoxicity induced by acetaminophen showed better improvement than either of them given alone, as in group IX (acetaminophen + cimetidine + silymarin) there was a highly significant $(\mathrm{p}<0.001)$ decrease in MDA hepatic tissue level as compared to group VI (acetaminophen), group VII (acetaminophen + silymarin) and group VIII (acetaminophen + cimetidine) and these results were non-significant as compared to controls.

The combination of silymarin and cimetidine resulted in an additive 
hepatoprotective effect with better improvement of MDA level (Giannioti et al., 2006).

Reduced glutathione (GSH) is an important non-enzymatic antioxidant that is responsible for the removal of different free radical species (Kaplowitz, 2000; Prakash et al., 2001 and Ibrahim et al., 2010).

The present work showed that the administration of acetaminophen produce a remarkable decrease of hepatic antioxidant GSH content. These results are in agreement with Rasool et al. (2010); Sujata et al. (2011); Sabiu et al. (2015) who reported a decrease in GSH activity in acetaminophentreated animals.

The significant decrease in GSH activity in acetaminophen treated rats can be explained by its consumption during the detoxification of reactive oxygen metabolites generated due to acetaminophen, as well as consumption of liver GSH store (Hamza and Al-Harbi, 2015).

Jack et al. (2010) and Rousar et al. (2012) supposed that the main mechanism of acetaminophen toxicity has been attributed to NAPQI formation. This highly reactive molecule can bind with $\mathrm{SH}$ groups of proteins thereby acetaminophen-adducts are formed. NAPQI can also react with glutathione producing acetaminophen-GS conjugate. This conjugation might be catalyzed with glutathione-S-transferase.

In the present work, treatment with acetaminophen and silymarin significantly increased the activity of the antioxidant hepatic GSH as compared to acetaminophen treated group.

Ramakrishnan et al. (2006); Parmar and Ghandi (2008); Shaarawy et al. (2009); Rasool et al. (2010) documented the protective effect of silymarin against acetaminophen-induced lipid peroxidation.

The results of the present work showed that treatment of rats with acetaminophen and cimetidine demonstrated a highly significant
( $p<0.001)$ increase in GSH level when compared to those of acetaminophen treated group or acetaminophen and silymarin treated group, although, these levels were still higher than that of the control group (showed significant difference with controls).

The present work is in accordance with Ahmadi et al. (2011) who found that cimetidine decreased the rate of GSH depletion.

The hepatoprotective effects of cimetidine may be related to its antioxidant activity in scavenging free radicals and free oxygen species such as $\mathrm{O}^{2-}$ and $\mathrm{OH}^{-}$, In addition, cimetidine is able to reduce the iron-induced rise in lipid peroxidation (Lambat et al., 2002).

The present work showed that combined treatment with cimetidine and silymarin for hepatotoxicity induced by acetaminophen showed better improvement than either of them given alone, as in group IX (acetaminophen + cimetidine + silymarin) there was a highly significant $(\mathrm{p}<0.001)$ increase in GSH hepatic tissue level when compared to group VI (acetaminophen), group VII (acetaminophen + silymarin) and group VIII (acetaminophen + cimetidine) and these results were non-significant as compared to controls.

Silymarin and cimetidine administration with acetaminophen improved GSH level probably due to synergistic hepatoprotective effect against APAP-induced liver damage (Zira et al., 2009).

Administration of silymarin or cimetidine, improved the GSH level comparing to the animals that received no antidote or those that received Nacetylcysteine. The combination of the two drugs resulted in an additive hepatoprotective (Giannioti et al., 2006).

Histopathological results supported the evidence of biochemical results in this study, as sections of rat liver treated with acetaminophen showed degeneration of 
hepatocytes (hydropic degeneration), dilatation of the blood sinusoids and congestion of central vein with marked loss of its normal pattern.

Hamza and Al-Harbi (2015) and Sabiu et al. (2015) showed that mice liver treated with paracetamol showed markedly congested central veins and congested dilated blood sinusoids. Also Adebiyi and Abatan (2013) and Bharali et al. (2014) showed severe centrilobular necrosis and the hepatocytes surrounding central vein shows extensive necrosis with vacuolar cytoplasmic degeneration after acute acetaminophen administration.

In acetaminophen and silymarin treated group, the present work showed liver regenerative changes as compared to acetaminophen treated group but failed to have the same picture observed in the normal control group. There was mild hydropic degeneration in hepatocytes, but there was no congestion and dilatation in the blood sinusoids and central vein indicating significant silymarin hepatoprotective effect.

Galal et al. (2012) and Singh et al. (2012) concluded that the use of silymarin succeeded to show better histopathological picture of the liver after acetaminophenintoxication but failed to have the same picture observed in the normal control group.

Liver sections of rats treated with acetaminophen and cimetidine revealed regenerative changes as compared to acetaminophen treated rats but failed to have the same picture observed in the normal control group, as there was regeneration of hepatocytes with no dilation of central vein or dilatation of sinusoids. Juma et al. (2015) fond that cimetidine provide protection of the histology of the liver following acetaminophen over dosage.

Histopathological examination of rats treated with both silymarin and cimetidine showed better improvement in liver morphology than that produced by either silymarin or cimetidine alone, as it showed apparent normal hepatic architecture. The present work is in accordance with Giannioti et al. (2006) in which silymarin and cimetidine co-administration with acetaminophen improved the histopathology probably due to additive hepatoprotective effect against acetaminophen-induced liver damage.

\section{CONCLUSION}

Treatment with cimetidine two hours after acetaminophen-induced hepatotoxicity gave better biochemical results as compared to treatment with silymarin, as there was a highly significant reduction in ALT and AST serum levels, and MDA liver tissue levels and a highly significant increase in GSH levels in liver tissue in group VIII (acetaminophen + cimetidine) as compared to group VII (acetaminophen + silymarin).

Treatment with cimetidine and silymarin in combination for hepatotoxicity induced by acetaminophen showed better improvement [biochemical and histopathological], than either of them given alone, probably due to synergistic hepatoprotective effect, as evidenced by:

a) A highly significant decrease in ALT, AST, MDA, and a highly significant increase in GSH in group IX (acetaminophen + cimetidine + silymarin) as compared to other tested groups, and these results were non-significant as compared to controls.

b) Histopathological examination of rats treated with combination of silymarin and cimetidine showed better improvement in liver morphology than that produced by either silymarin or cimetidine alone. 


\section{RECOMMENDATIONS}

- It is recommended to use combination of silymarin and cimetidine for treatment of chemically-induced hepatotoxicity.

- Additionally silymarin and cimetidine may be used for production of a safe form of acetaminophen due to their hepatoprotective properties.

- Moreover, it is required to perform further studies combining silymarin with cimetidine in attenuation of hepatic insufficiency in human subjects.

\section{ACKNOWLEDGEMENT}

Our deep appreciation to the staff members of Forensic Medicine \& Clinical Toxicology; Anatomy and Pathology Departments, Faculty of Medicine, Banha University, for their cooperation. Http://www.fmed.bu.edu.eg.

\section{REFERENCES}

Abdei-Hady, E.K. and Abdei-Rahman, G.H. (2013): Protective role of coenzyme Q10 against paraquat induced hepatotoxicity in male rats. J. Life Sci., 10 (1): 1933-1940.

Abirami, A.; Nagarani, G. and Siddhuraju, P. (2015): Hepatoprotective effect of leaf extracts from Citrus hystrixand C. maxima against paracetamol induced liver injury in rats. Food Sci. Human Wellness , 4(1): 35-41.

Adebiyi, O.E. and Abatan, M.O. (2013): Protective Effects of Enantia chlorantha Stem Bark Extracts on Acetaminophen Induced Liver Damage in Rats. Jor. J. Biol. Sci., 6(4): $284-290$.

Adikwu, E. and Bokolo, B. (2018): Effect of cimetidine on cyclophosphamideinduced liver toxicity in albino rats. Asian J. Med. Sci., 9(5): 50-56.
Ahmadi, A.; Ebrahimzadeh, M.A.; AhmadAshrafi, S.; Karami, M.; Mahdavi, M.R. and Saravi, S.S. (2011): Hepatoprotective, antinociceptive and antioxidant activities of 12 cimetidine, ranitidine and famotidine as histamine H2 receptor antagonists. Fundam. Clin. Pharmacol., 25(1):72-79.

Akindele, A.J. and Adeyemi, O.O. (2010): Anxiolytic and sedative effects of Byrsocarpus coccineus Schumman and Thonningia (Connaraceae) extract. Int. J. Appl. Research Nat.Prod., 3:28-36.

Al-Mustafa, Z.H.; Al-Ali, A.K.; Qaw, F.S. and Abdul-Cader, Z. (1997): Cimetidine enhances the hepatoprotective action of $\mathrm{N}$-acetylcysteine in mice treated with toxic doses of paracetamol. Toxicol., 121(3): 223-228.

Anthony, K.P. and Saleh, M.A. (2013): Free radical scavenging and antioxidant activities of silymarin components. Antioxidants, 2(4):398-407.

Arote, S.; Gupta, S.K.; Lodha, P.; Yaday, $P$. and Lodha, M. (2014): Hepatoprotective activity of herbal formulation against paracetamolinduced hepatotoxicity in rats. Indo Am. J. Pharmaceu. Research., 4(1): 451-456.

Bairwa, N.K.; Sethiya, and Mishra, S. (2010): Protective effect of stem bark of Ceiba Pentandra against paracetamol-induced hepatotoxicity in rats. Pharmacognosy Research., 2: 26 30.

Beutler, E.; Duron, O. and Kelly, B. (1963): Improved method for the determination of blood glutathione. J Lab. Clin. Med., 61:882-888.

Bharali, K.M.; Konya, H. and Chetry, L.B. (2014): Protective effect of 
Oroxylum indicum on acetaminophen induced liver injury in rat. J. Int. Curr. Pharmaceu., 3(2): 223-227.

Caparrotta, T.M.; Antoine, D.J. and Dear, J.W. (2017): Are some people at increased risk of paracetamol-induced liver injury? A critical review of the literature. Eur. J. Clin. Pharmacol., 74(2):147-160.

Chattopadhyay, A.; Biswas, S.; Bandyopadhyay, D.; Sarkar, C. and Datta, A.G. (2003): Effect of isoproterenol on lipid peroxidation and antioxidant enzymes of myocardial tissue of mice and protection by quinidine. Molec. Cell. Biochem., 245: 43-49.

Daly, F.; Fountain, J.; Murray, L.; Graudins, A. and Buckley, N. (2008):"Guidelines for the management of paracetamol poisoning in Australia and New Zealand - explanation and elaboration. A consensus statement from clinical toxicologists consulting to the Australasian poisons information centres". J. Med. Aust., 188 (5): 296301.

Datta, S.; Dhar, S.; Nayak, S. and Dinda, S.C. (2013): Hepatoprotective activity of Cyperus articulatus Linn.against paracetamol induced hepatotoxicity in rats. J. Chem. Pharmaceu. Research., 5(1): 315319.

Ebrahimi, M.; Mousavi, S.R.; Toussi, A.G.; Reihani, H. and Bagherian, F. (2015): Comparing the Therapeutic Effectiveness of $\mathrm{N}$-acetylcysteine with the Combination of $\mathrm{N}$-acetyl Cysteine and Cimetidine in Acute Acetaminophen Toxicity: A Double-Blinded Clin. Trial Electron Physician, 7(6): 1310-1317.

El-Ashmawy, I.; El-Nahas, A. and Salama, O. (2005): Protectiveeffect of volatile oil, lcoholicand aqueous extracts of Origanummajörana on lead acetate toxicity in mice. Basic Clin. Pharmacol. Toxicol., 97:238-243.

El-Sayed, E.M.; Mansour, A.M. and Nady, M.E. (2015): Protective Effects of Pterostilbene against Acetaminophen-Induced Hepatotoxicity in Rats. J. Biochem. Molecu. Toxicol., 29 (1): 35-42.

Gaafa, K.M.; Badawy, M.M. and Hamza, A.A.(2011): The protective effects of ascorbic acid, cimetidine, and nifedipine on diethyldithiocarbamate-induced hepatic toxicity in albino rats. Drug Chem. Toxicol., 34(4):405-19.

Galal, R.M.; Zaki, H.F.; Seif El-Nasr, M. and Agha, A.M. (2012): Protective effect of honey against paracetamol-induced hepatotoxicity. Arch. Iran Med., 15(11):674-80.

Giannioti, K.; Papalois, A.; Theocharis, S.; Liapi, C. and Drakoulis, N. (2006): Additive hepatoprotective effect of silybinin, naringenin and cimetidine against paracetamol-induced hepatotoxicity in rabbits. Epitheorese Klin. Farmakol. Farmakokinet., 20(2): 90-93.

Girish, C.; Koner, B.C.; Jayanthi, S.; Ramachandra Rao, K.; Rajesh, B. and Pradhan, S.C. (2009): Hepatoprotective activity of picroliv, curcumin and ellagic acid compared to silymarin on paracetamol induced liver toxicity in mice. Fundam. Clin. Pharmacol., 23(6):735-45.

Hamza, R.Z. and Al-Harbi, M.S. (2015): Amelioration of paracetamol hepatotoxicity and oxidative stress on mice liver with silymarin and Nigella sativa extract supplements. Asian Pacific J. Trop. Biomed., 5(7): 521-531. 
Heard, K. and Schaeffer, T.H. (2011): Massive acetylcysteine overdose associated with cerebral edema and seizures. Clin. Toxicol. (Phila)., 49: 423425.

Hellerbrand, C.; Schattenberg, J.; Peterburs, P. (2016): The potential of silymarin for the treatment of hepatic disorders .Int.J.of Phytomed. \& Phytotherap., 2:(7):12-22.

Ibrahim, M.; Abdul, A.; Ibrahim, A.; Abdel Wahab, S.; Elhassan, M. and Mohan, S. (2010): Attenuation of cisplatininducednephrotoxicity in rats using zerumbone. Afr. J. Biotechnol., 4434 4441 .

Jack, A.; Dean, W. and Laura, P. (2010): Mechanisms of acetaminophen- induced liver necrosis. Hand. Exp. Pharmacol., (196): 369-405.

Jahangirvand, M.; Minai-Tehrani, D.; Yazdi, F.; Minai-Tehrani, A. and Razmi, $N$ (2016): Binding of Cimetidine to Balb/C Mouse Liver Catalase; Kinetics and Conformational Studies. Curr. Clin. Pharmacol., 11(1):21-7.

Javad, S.; Mahdi, S. and Reza, E.M. (2009): Therapeutic effect of cimetidine on acetaminophen-induced hepatotoxicity in rabbits. Compar. Clin. Pathol., 18 (3):325-328.

Juma, K.K.; Maina, S.G.; Muriithi, J.N.; Mwangi, B.M.; Mworia, K.J. (2015): Protective effects of urtica dioica and cimetidine on liver function following acetaminophen induced hepatotoxicity in mice. J. Develop. Drugs, 4: 130.

Kaplowitz, N. (2000): Mechanism of liver cell injury. J. Hepatol., 32:39-47.

Kazemifar, A.M.; Hajaghamohammadi, A.A.; Samimi, R.; Alavi, Z.; Abbasi, E. and Asl, M.N. (2012): Hepatoprotective property of oral silymarin is comparable to N-Acetylcysteine in acetaminophen poisoning. Gastroenterol. Res., 5(5): 190-194.

Khothari, C.R. (2004): Research Methodology: Methods and Techniques, New Age International, New Delhi.

Lambat, Z.; Limson, J.L. and Daya, S. (2002): Cimetidine: antioxidant and metal-binding properties. J. Pharm. Pharmacol., 54(12):1681-1686.

Lamberg, S. and Rothstein, R. (eds.) (1978): Laboratory Manual ofHistology and Cytology. 2nd ed., A.V.I. Publishing Company, West Port Connecticut, pp: 137-140.

Mc Quaid, K.R. (2003): Drugs used in the treatment of gastrointestinal diseases. In Basic and Clinical Pharmacology.Katzung $\quad$ B.G. $9^{\text {th }}$ ed. Lang Medical Books/Mc Graw-Hill.New York ., pp:1034-1063.

Navdeep, S.; Divneet, C. and Sara, B. (2010): Amelioration ofparacetamol induced hepatotoxicity by a protein isolated fromthe leaves of the herb Cajanus Acutifolius Linn. Int. J. Pharm. Pharmaceu. Sci., 2 ( 3): 75-80.

Pandey; Govind and Sahni, Y. (2011): Review on hepatoprotective activity of silymarin. Int. J. Res. Ayur. Pharm., 2(1): 75-79.

Parmar, M.Y. and Gandhi, T.R. (2008): Hepatoprotective herbal drug, silymarin from experimental pharmacology to clinical medicine. Pharmacognosy Reviews., 2(3):102-109.

Pradeep, K.; Mohan, C. and Gobianand, K. (2007): Silymarinmodulates the oxidant antioxidant imbalance duringdiethylnitrosamine induced oxidative stress in rats. Eur J. Pharmacol., 560(2/3):110-116. 
Prakash, J.; Gupta .S. and Singh .N. (2001):Chemopreventive activityof Withania somnifera in experimentally induced fibro sarcomatumors in Swiss albino rats. Phytother Res., 15: 200-204.

Rajasekaran, A. and Periyasamy, $M$. (2012): Hepatoprotective effect of ethanolic extract of trichosanthes lobata on paracetamo1-induced liver toxicity in rats. Chinese Med., 2(12): 1-6.

Ramakrishnan, G.; Raghavendran, H.; Vinodhkumar, $R$. and Devaki, $T$. (2006): Suppression of Nnitrosodiethylamineinduced hepato carcinogenesis by silymarin in rats. Chem. Biol. Interact., 161, 104-114.

Rasool, M.K.; Sabina, E.P.; Ramya, S.R.; Preety, P.; Patel, S. and Mandai, N. (2010): Hepatoprotective and antioxidant effects of gallic acid in paracetamol induced liver damage in mice . J. Pharmcol. Pharmacotherap., 62: 638-643.

Rouser, T.; Nydlova, E.; Česla, P.; Stankova, P.; Kucera, O.; Parik, P. and Červinkova, Z. (2012): Acetaminophen-Glutathione Conjugate Is Able To Induce Oxidative Stress in Rat. Liver Mitochondria. Physiol. Res., 61 (2): 103-109.

Sabina, E.; Rasool, M.; Vedi, M.; Nananeethan, D.; Ravichander, M.; Parthasarthy, P. and Thelia, S. (2013): Hepatoprotective and antioxidant potential of withania somnifera against paracetamol induced liver damage in rats. Int. J. Pharm. Pharmaceu. Research., 5(2): 648-671.

Sabiu, S.; Sunmonu, T.O.; Ajani, E.O. and Ajiboye, T.O. (2015): Combined administration of silymarin and vitamin C stalls acetaminophen-mediated hepatic oxidative insults in Wistar rats. Revista Brasileira de Farmacognosia., 25(1): 2934.

Saito, C.; Zwingmann, $C$. and Jaeschke, $H$. (2010): Novel mechanisms of protection against acetaminophen hepatotoxicity in mice by glutathione and $\mathrm{N}$ acetylcysteine. Hepatol., 51: 246-254.

Salhanik, S.D. (2010): Acetaminophen in: Essentials of Emergency Medicine. Aghababian, $2^{\text {nd }}$ ed., Burlington: Jones \& Bartlett Publisher; Massachusetts. pp: 814-817.

Shaarawy, S.M.; Tohamy, A.A.; Elgendy, S.M.; Abd Elmageed, Z.Y.; Bahnasy, A.; Mohamed, M.S.; Kandil, E. and Matrougui, K. (2009): Protective effects of garlic and silymarin on ndeainduced rats hepatotoxicity. Int. J. Biol. Sci., 5(6): 549-557.

Shah, V.N. and Deval, K. (2011): Heatoprotective activity of leaves of Parkinsonia aculeata Linn against paracetamol induced hepatotoxicityin rats. Int. J. Pharm., 1(2): 59-66.

Singh, G.; Goyal, R. and Sharma, P.L. (2012): Pharmacological potential of silymarin in combination with bepatoprotectiv plants against experimental hepatotoxicity in rats. Asian J. Pharmaceu. Clin. Research., 5(1): 128-133.

Sujata, S.; Shanker, K.; Mritunjay, K.; Kalpana, C. and Rashmi, S. (2011): Ameliorative potential of quercetin againstparacetamol-induced oxidative stress in mice blood. Toxicol. Int., 18(2): 140-145.

Suleyman, C.; Serhat, T.; Bulent, C.; Hasan, E.; Recep, A.; Serpil, C.; Huseyin, S.; Atilla, I.; Selim, S. and Yilmaz, P. (2015): The effect of silymarin on hepatic regeneration after 
partialhepatectomy: is silymarin effective in hepatic regeneration? Int. J. Clin. Exp. Med., 8(2): 2578-2585.

Suresh, K.; Sujatha, C.; Syamala, J.; Nagasudha, B. and Mishra, S. (2006): Protective effect of root extract of Operculina turpethumL. against paracetamol-induced hepatotoxicity in rats. Ind. J. Pharm. Sci., 68:32-35.

Zira, A.; Mikros, E.; Giannioti, K.; Galanopoulou, P.; Papalois, A.; Liapic, C. and Theocharisa, S. (2009): Acute liver acetaminophen toxicity in rabbitsand the use of antidotes: a metabonomicapproach in serum. J. Appl. Toxicol., 29: 395-402. 


\section{الملخص العربي}

\section{التاثير المحسن لعقارى السيميتيدين والسيليمارين على التسمم الكبدى الحاد لعقار

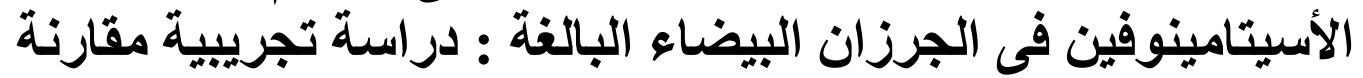

\section{المشتركون فى البحث}

أسماء عبد العزيز سليمان، عاطـف عبدالعزيز فــودة، اســلام ســـــى متولى ، عبــ المنعـم جـودة

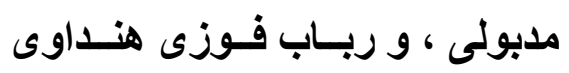

قسم الطب الثر عى و السموم الأكلينيكية، كلية الطب البشري - جامعة بنها ـ مصر

الأسيتامينوفين هو دواء مسكن وخافض للحرارة، تسبب جر عته الزائدة سمية كبدية. و الترياق الحالي

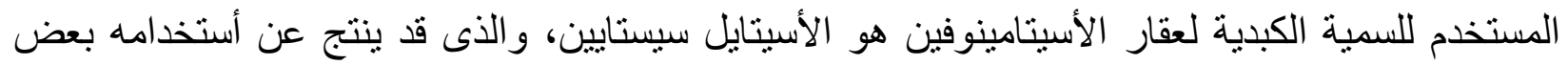
الآثار الجانبية الخطيرة مثل نوبات الصرع، وارتفاع ضغط الدم والأسنسقاء بالمخ. هدفت هذه الدر اسة لتقييم

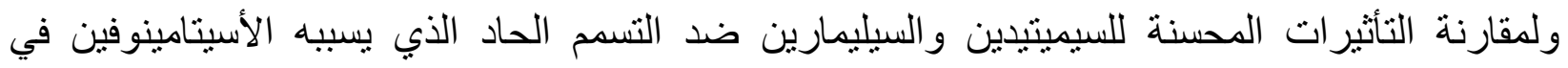

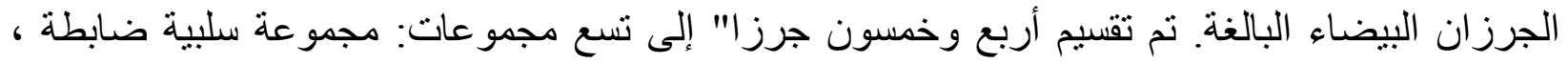

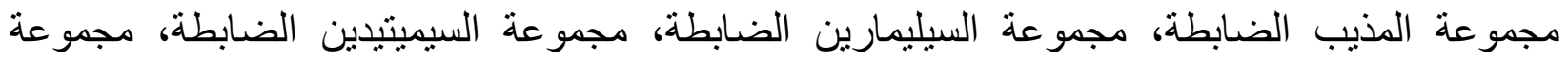
السيميتيدين و السيليمارين الضابطة، مجموعة الأسيتامينوفين، مجموعة الأسيتامينوفين و السيليمارين،

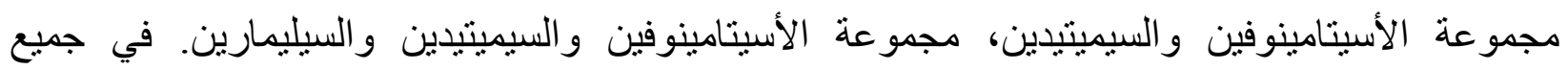
المجمو عات كانت جر عة الاسيتامينوفين 800 مج / كج (جرعة و احده بالفم)، وكانت جر عة سيليمارين 150 مج / كم (جرعة واحده بالفم) ، وكانت جرعة السيميتيدين 150 مج / كم (جرعة واحده حقنا بالغشاء البريتونى). في نهاية الدراسة تم فحص الأنسجة الكبدية بالميكروسكوب الضوئى، كما تم إجراء تحليلات كيميائية حيوية شملت قياس مستوي إنزيمات الكبد، قياس مستوي أحد مؤشرات إجهاد التأكسد و قياس التهاس

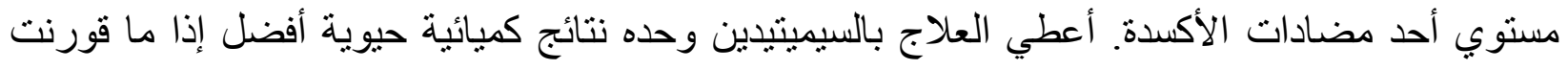
بالعلاج بالسليمارين وحده. مع ذلك أظهر اللعلاج المزدوج بالسيميتيدين والسليمارين تحسن أفضل من تلك

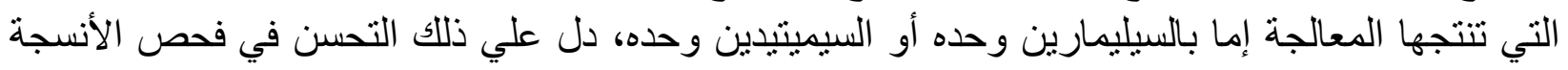
الكبدية بالميكروسكوب الضوئى و نتائج التحليلات الكيميائية الحيوية مقارنة بباقي مجموعات التينة الدراسة، في

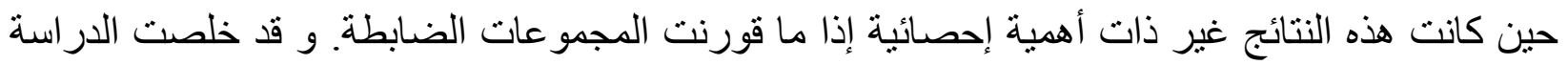
الى أن العلاج بالسيليمارين و السيميتيدين معا له تأثير تآزري للعقارين في حماية الكبد مما يعطى نتائج أفضل فئل فى علاج التسمم الكبدى الحاد الذي يسببه الأسيتامينوفين 